\title{
Basic characteristics of microhabitats of snake-eyed skink (Ablepharus kitaibelii) in Western Hungary
}

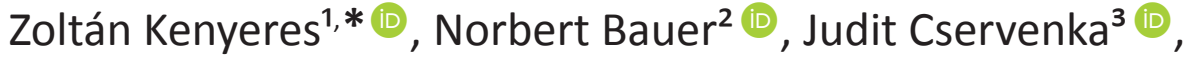 \\ Szilárd Szabó ${ }^{4}$ (1) \& Sándor Tóth ${ }^{5}$
}

Key words: reptile, ecotone, edge habitat, microclimate, soil, climate change, dolomite, vegetation.

Ključne besede: plazilci, ekoton, robni habitat, mikroklima, tla, podnebne spremembe, dolomit, vegetacija.

Received: 08. 02. 2020

Revision received: 24. 03. 2020

Accepted: 25. 03. 2020

Co-ordinating Editor:

Rocco Labadessa

\begin{abstract}
Following the rediscovery after 200 years of Ablepharus kitaibelii fitzingeri in 2017, we carried out data collection its habitats regarding vegetation, microclimate, and soil on two prominent dolomite hills of the Eastern Bakony. Data collections were carried out in habitat mosaics (xerothermic forest edges on the plateaus, karst shrub forests in south-facing exposure, dry grasslands among forest patches on the plateaus, rocky grasslands in south-facing exposure) of three sampling blocks. Vegetation was examined by phytosociological relevés, microclimate from April to November continuously by TMS-2 dataloggers, and soil by laboratory analyses focused mainly on percentage of different fractions. According to our results a) shrub forests with a south-facing exposure provide a cooler microclimate with temperated fluctuation in the spring-early summer and late summer-early autumn periods; b) plateau grasslands and shrubs are characterised by looser soil structure. Based on our results, heterogeneous habitat character of forest-grassland mosaics of the Pannonicum can mitigate the expected negative effects of climate change on reptiles.
\end{abstract}

\begin{abstract}
Izvleček
Leta 2017 so po 200 letih ponovno našli vrsto Ablepharus kitaibelii fitzingeri, zato smo izvedli raziskavo o njenem habitatu: vegetaciji, mikroklimi in tleh na dveh dolomitnih vzpetinah v vzhodnem delu pokrajine Bakony. Podatke smo zbirali v habitatnem mozaiku (kserotermni gozdni robovi na platojih, kraški grmičasti gozdovi na južnih pobočjih, suha travišča med gozdnimi zaplatami na platojih, kamnita travišča na južnih pobočjih) v treh vzorčnih blokih. Vegetacijo smo preučili s fitocenološkimi popisi, mikroklimo smo merili kontinuirano med aprilom in novembrom z TMS-2 datalogerji, z laboratorijskimi analizami tal pa smo določili deleže posameznih frakcij. Naši rezultati kažejo da imajo grmičasti gozdovi na južnih pobočjih hladnejšo mikroklimo z zmernim nihanjem spomladi in zgodaj poleti ter pozno poleti in zgodaj jeseni, travišča in grmišča na platojih pa imajo bolj nevezano strukturo tal. Na osnovi naših rezultatov lahko heterogenost habitata gozdno-traviščnega mozaika v Panoniji ublaži negativne učinke podnebnih sprememb na plazilce.
\end{abstract}

\footnotetext{
1 Acrida Conservational Research L.P., Deák F. street 7, H-8300, Tapolca, Hungary. E-mail: kenyeres@acridabt.hu

2 Department of Botany, Hungarian Natural History Museum, Könyves K. krt. 40, H-1087, Budapest, Hungary. E-mail: bauer.norbert@nhmus.hu

3 Balaton Uplands National Park Directorate, Kossuth street 16, H-8229, Csopak, Hungary. E-mail: cservenka@bfnp.hu

4 Department of Physical Geography and Geoinformatics, University of Debrecen, Egyetem square 1, H-4032, Debrecen, Hungary. E-mail: szaboszilard.geo@gmail.com

5 Independent researcher, Széchenyi street 2, H-8420, Zirc, Hungary. E-mail: flycatcher@vnet.hu

* Corresponding author
} 


\section{Introduction}

Ablepharus kitaibelii (Bibron \& Bor, 1933), or snake-eyed skink, is a species of European importance (Böhme et al. 2017). The lizard is listed in the Bern Convention (Council of Europe 1994, Appendix 2) and the European Union Habitat Directive (Annex IV, species in need of strict protection), and is a protected species in several countries (e.g. Croatia, Hungary). In Hungary, it is a strictly protected species and is included in the Red List as potentially endangered species (Rakonczay 1989).

The snake-eyed skink is distributed from southern Slovakia to Hungary and through the Balkans to Greece and Turkey - including the Aegean and Ionian islands, with extreme population fragmentation at the edges of its distribution (in Croatia, Bosnia and Herzegovina, Hungary) (Sillero et al. 2014). Most of the former publications have focused on the occurrence and taxonomy of $A$. kitaibelii, but also several papers studied its ecological requirements and behaviour (Pasuljević 1965, 1966, 1975, 1976, Herczeg et al. 2007a, Natchev et al. 2015, Kovács \& Kiss 2016, Vergilov 2017, Zimić et al. 2018, Vergilov \& Kornilev 2019). The main habitats of the species are grasslands surrounded by woody vegetation patches and ecotone habitats (Ljubisavljević et al. 2002, Herczeg et al. 2007a, Zimić et al. 2018). Due to its body morphology (short, thin body, reduced-size legs), it avoids large, continuous rock surfaces (Herczeg et al. 2007a).

Females bury their soft eggs in loose soil or fallen foliage and adults spend their shorter or longer inactive periods burrowed in the ground (Herczeg \& Korsós 2003, Herczeg et al. 2007a). Ablepharus kitaibelii prefers smallsize, flightless arthropods; its food depends on the habitat and does not appear to be a decisive factor (Natchev et al. 2015), but is largely made of ants (Herczeg et al. 2007a).

This taxon occurs in the southern part of Slovakia, in Hungary and the northern part of Serbia $A$. $k$. fitzingeri (Teschler 1885, Fejérváry 1912, Mertens 1952, Szunyoghy 1954, Fuhn 1969, Gruber 1981, Ljubisavljević et al. 2002, Herczeg et al. 2004). In Hungary, A. k. fitzingeri populations are known mostly in some sub-areas of the Hungarian Middle Mountain Range, but their local area extends to the Danube-Tisza Interfluve (Duna-Tiszaköze) as well (Herczeg et al. 2004, Puky et al. 2005) (Figure 1). With regard to Hungarian data, the specimen from the Eastern Bakony Mountains labelled as "Palota" in literature (now called Várpalota), under the name Lacerta nitida (in the notes recorded in 1799 by Pál Kitaibel, see in Horváth 1918, Molnár V. 2007) had been treated as historical, and of uncertain occurrence until recent years (Herczeg et al. 2004). More than 200 years after the first observation of the species, in 2014 and 2015, several specimens of the species were rediscovered near the town of Várpalota (Tés: Móroc-tető and Tés: Bérhegy) (Tóth 2015).

As habitat requirements of the species have not been explored widely enough in its typical microhabitat networks, a detailed survey of the habitat conditions is needed. Besides data collection on soil and plant-coenological parameters, we carried out continuous microclimate measurements covering the active period of the species (from April to November). Based on these fine-scale data, our research was focused on assessing the habitat constraints limiting the occurrence of $A$. $k$. fitzingeri in the study area. Results are discussed with regard to local conservation possibilities and relevant risks associated with climate change.

\section{Methods}

Móroc-tető (Mt) and Bér-hegy (Bh) are two prominent dolomite hills of the Eastern Bakony (Figure 1). On the south-facing sides, on the plateau edges and the plateaus of the hills, the extent of natural dry grasslands is substantial (grasslands on the south-facing sides: Mt: $\sim 10$ hectares, Bh: $\sim 9$ hectares; grasslands on the plateau edges and the plateaus: Mt: -7 hectares, Bh: -12 hectares). Our fieldwork covered the entire study area $(-7$ $\mathrm{km}^{2}$ ) but focused on the grassland-shrub forest mosaics $\left(-1 \mathrm{~km}^{2}\right)$. Between 2011 and 2018, we spent a total of 25 days searching for the species. We took into account the fact that the species is characterised by bimodal activity on both a daily and a yearly basis, as a result of the thermoregulation of the species due to its body size (Herczeg et al. 2007b). The most active periods of the species are the morning (07:00-10:00) and late afternoon (16:00-17:00) (Pasuljević 1976), further the spring and autumn (Herczeg et al. 2007a). Following the discovery of $A$. k. fitzingeri, we carried out data collection regarding vegetation, habitat structure, microclimate, and soil structure. Data were collected in three sampling blocks, i.e. habitat mosaics: one block in Móroc tető; two blocks in Bér-hegy (Figure 1). We established four $50 \times 50 \mathrm{~m}$ quadrats (one for each habitat with gradient-like differences) in each block: xerothermic forest edges on the plateaus (A), karst shrub forests in south-facing exposure (B), dry grasslands among forest patches on the plateaus (C), rocky grasslands in south-facing exposure (D). For each $50 \times 50 \mathrm{~m}$ quadrats, three $4 \times 4 \mathrm{~m}$ phytosociological relevés were made for the grass layer (even in shrub forests and pubescent oak forest edges) with the Braun- 


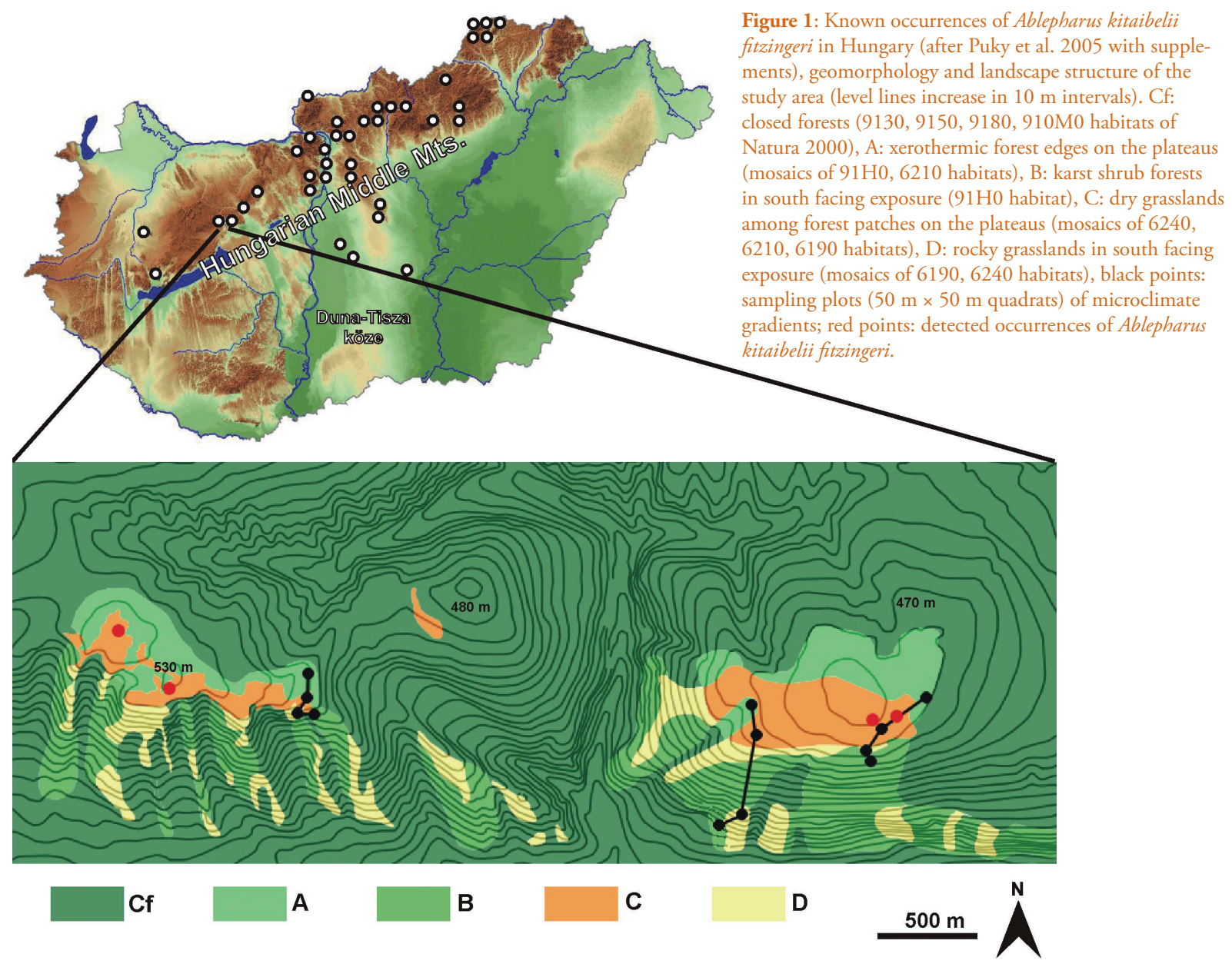

Slika 1: Znana nahajališča vrste Ablepharus kitaibelii fitzingeri na Madžarskem (po Puky et al. 2005 z dodatki), geomorfologija in krajinska struktura preučevanega območja (izohipse so na 10 m). Cf: sklenjen gozd (habitati Natura 2000 9130, 9150, 9180, 910M0), A: kserotermni gozdni robovi na platojih (mozaik habitatov 91H0, 6210), B: kraški grmičasti gozdovi na južnih pobočjih (habitat 91H0), C: suha travišča med gozdnimi zaplatami na platojih (mozaik habitatov 6240, 6210, 6190), D: kamnita travišča na južnih pobočjih (mozaik habitatov 6190, 6240), črne točke: vzorčne ploskve (kvadrati $50 \mathrm{~m} \times 50 \mathrm{~m}$ ) na mikroklimatskem gradientu; rdeče točke: opaženo pojavljanje vrste Ablepharus kitaibelii fitzingeri.

Blanquet method (Dierschke 1994), recording plant species coverage as percentage values. Further habitat variables were used for the analyses: bare rock surface (\%), fallen foliage cover $(0.1-5 \%,>5 \%)$, average height $(\mathrm{cm})$ of the herb layer, relative frequencies of phanerophytes in phytocoenological relevés. For the microclimate measurements, two TMS-2 type dataloggers were fixed into the ground in each quadrat (we used data calculated by averaging the measured series of the two instruments). From 1 April to 30 November 2017, the 24 instruments recorded the soil surface-temperature values every 10 minutes. We calculated the monthly fluctuations of daily minimums, daily maximums, daily averages, and daily range of temperature. For soil analyses, two soil samples were taken in each quadrat, whereby the averaged values of the following variables were determined: the percent- age of different fractions (gravel: $2-4 \mathrm{~mm}$; sand - very coarse: $1-2 \mathrm{~mm}$; sand - coarse: $0.63-1 \mathrm{~mm}$; sand - intermediate coarseness: $0.63-0.2 \mathrm{~mm}$; sand - slightly coarse: $0.1-0.2 \mathrm{~mm}$; sand - fine: $0.1-0.05 \mathrm{~mm}$; sand - powder: $0.02-0.05 \mathrm{~mm}$; silt: $0.01-0.02 \mathrm{~mm}, 0.005-0.01 \mathrm{~mm}$, and $0.002-0.005 \mathrm{~mm}$; loam: $0.001-0.002 \mathrm{~mm}$, and $<0.001 \mathrm{~mm}$ ), percentage of mould content. Differences among environmental parameters were analysed by paired t-tests. Statistical procedures were performed with the PAST 2.16 software package (Hammer et al. 2001). The landscape structure of the study area was analysed and depicted with the use of Quantum GIS (version 1.8), topographical maps and aerial photographs. 


\section{Results}

Ablepharus k. fitzingeri was found on plateau grasslands with patches of shrub forest $(\mathrm{C})$, and in their margins contacting karst shrub forests in south-facing exposure (B) on both hills (Figure 1). In the plateau grasslands (C), bare rock surfaces occupy a significantly larger area than in the xerothermic forest patches (A, B). Whereas, in plateau grasslands $(\mathrm{C})$ there are no such large continuous rock surfaces present as in the exposed rocky grasslands (D) (Figure 2a). Presence of litter of the fallen foliage was most dominant on xerothermic woody patches (A, B), but its amount did not show a significant difference
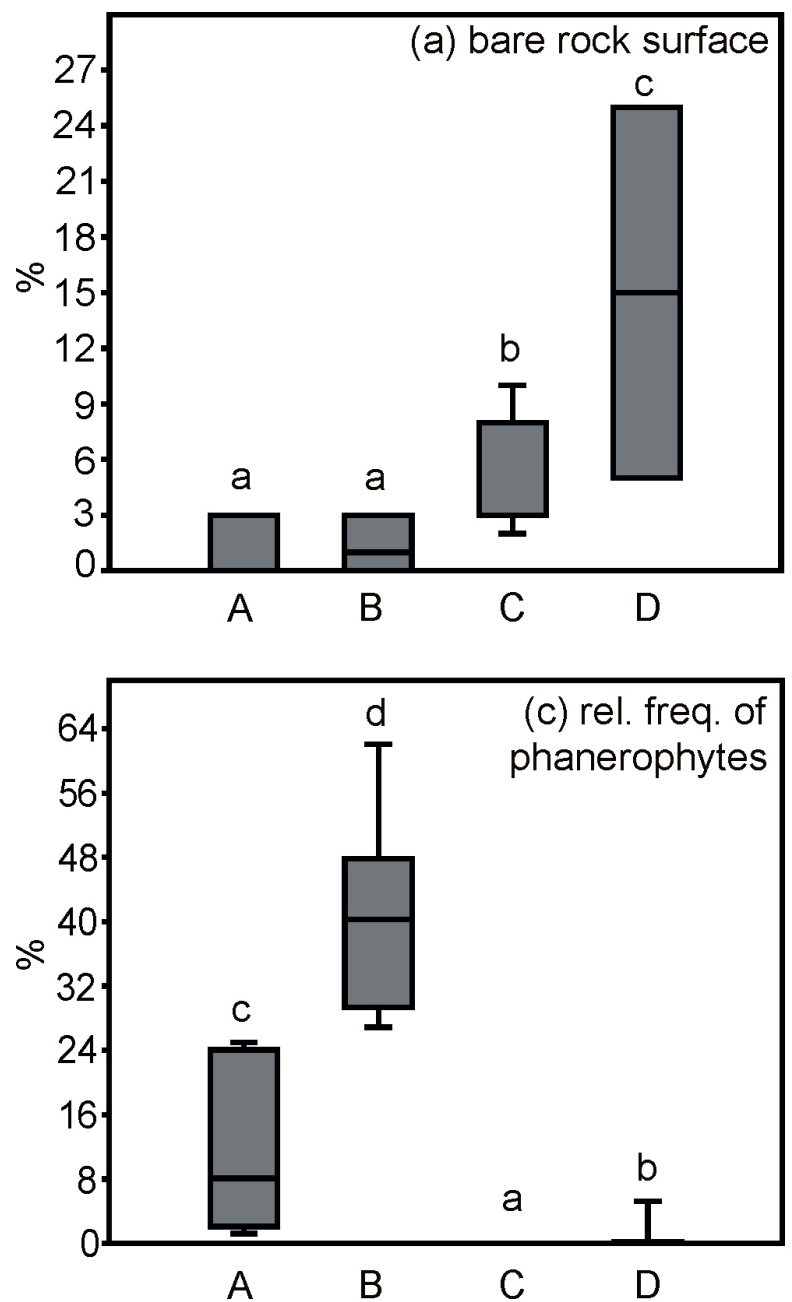

between the margins of xerothermic pubescent oak forests of the plateau (A) and the grasslands of the slopes (D) (Figure 2b). The relative frequency of phanerophytes in the grass layer of vegetation was higher in the shrub forest patches than in the grasslands, and in the exposed habitat patches (in the cases of both shrub forests and grasslands) it was significantly higher than in the plateau sites (Figure 2c). The height of the herb layer in the shrub forests was significantly higher than in the grasslands. In addition, this index was significantly higher at the edge of the xerothermic pubescent oak forest of the plateau (A) than was the case in the exposed shrub forests (B) (Figure 2d). In May, which falls in the active period of A. $k$. fitzingeri, the maximum daily temperature values
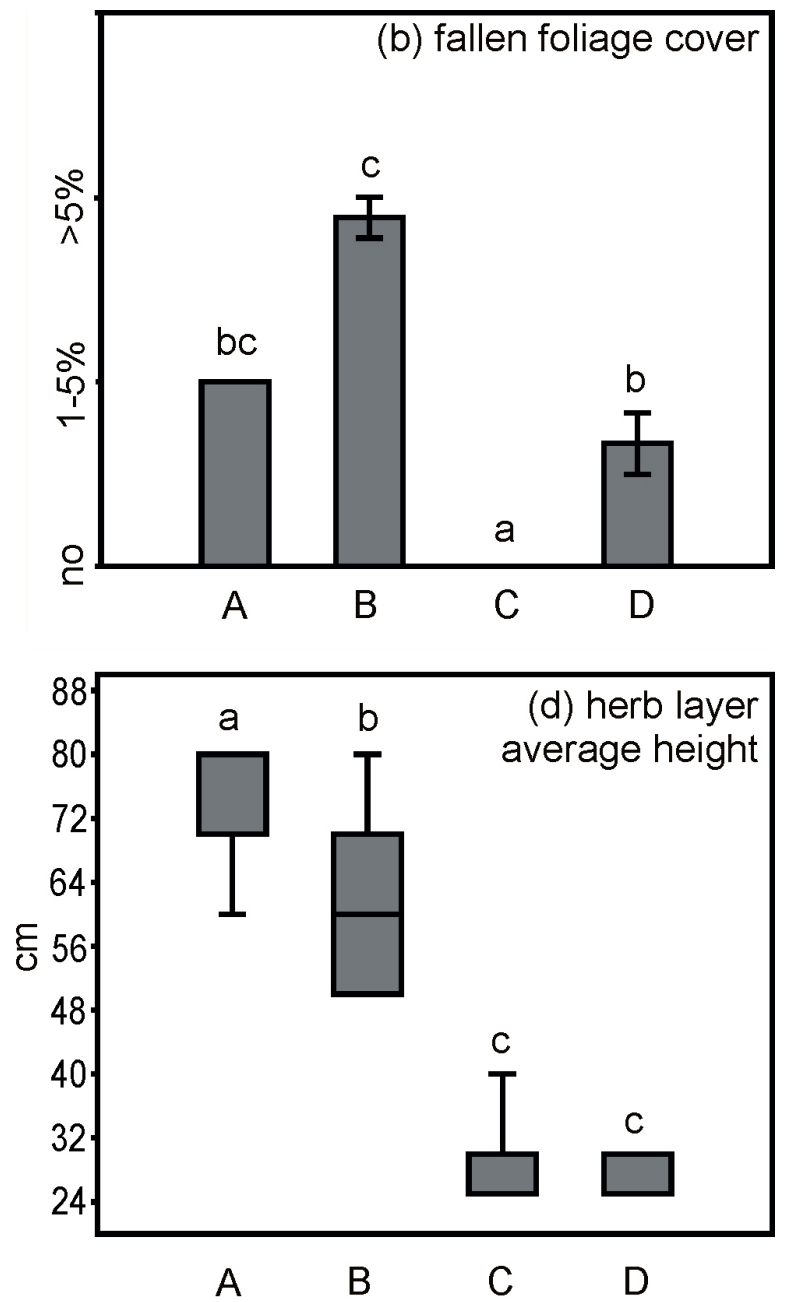

Figure 2: Mean values (min-max and \pm SE) of the most determinative habitat parameters in the studied habitats. Different letters indicate significant differences between parameters at $\mathrm{P}<0.05$. A: xerothermic forest edges on the plateaus, B: karst shrub forests in south facing exposure, $\mathrm{C}$ : dry grasslands among forest patches on the plateaus, D: rocky grasslands in south facing exposure.

Slika 2: Povprečne vrednosti (min-max in \pm SE) najbolj pomembnih habitatnih dejavnikov v obravnavanih habitatih. Različne črke predstavljajo značilne razlike med dejavniki $(\mathrm{P}<0,05)$. A: kserotermni gozdni robovi na platojih, B: kraški grmičasti gozdovi na južnih pobočjih, C: suha travišča med gozdnimi zaplatami na platojih, D: kamnita travišča na južnih pobočjih. 

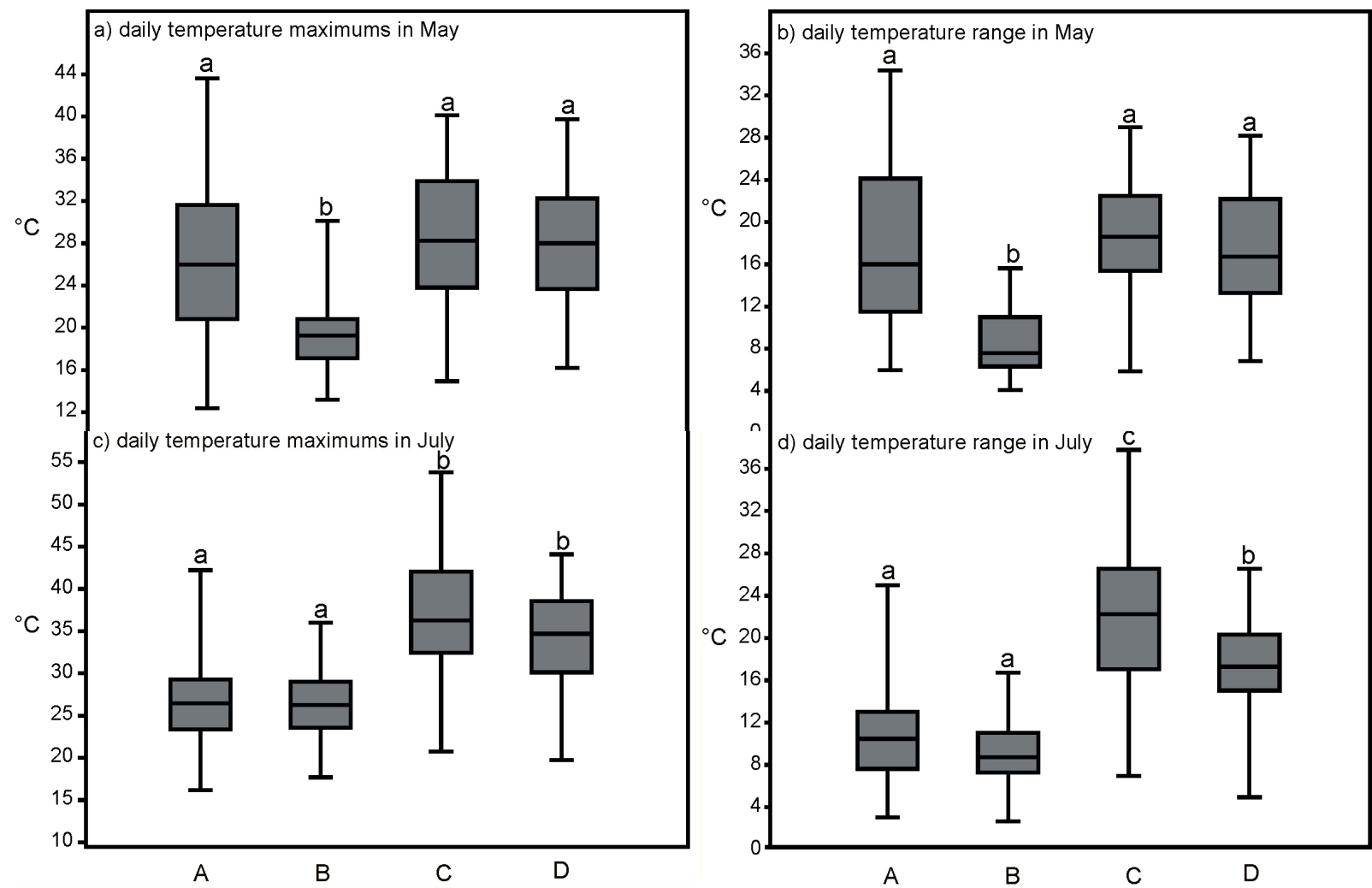

Figure 3: Mean values (min-max and \pm SE) of the most determinative microclimatic parameters in the studied habitats. Different letters indicate significant differences between parameters at $\mathrm{P}<0.05$. A: xerothermic forest edges on the plateaus, B: karst shrub forests in south facing exposure, C: dry grasslands among forest patches on the plateaus, D: rocky grasslands in south facing exposure.

Slika 3: Povprečne vrednosti (min-max and \pm SE) najbolj pomembnih mikroklimatskih dejavnikov v obravnavanih habitatih. Različne črke predstavljajo značilne razlike med dejavniki $(\mathrm{P}<0,05)$. A: kserotermni gozdni robovi na platojih, B: kraški grmičasti gozdovi na južnih pobočjih, C: suha travišča med gozdnimi zaplatami na platojih, D: kamnita travišča na južnih pobočjih.
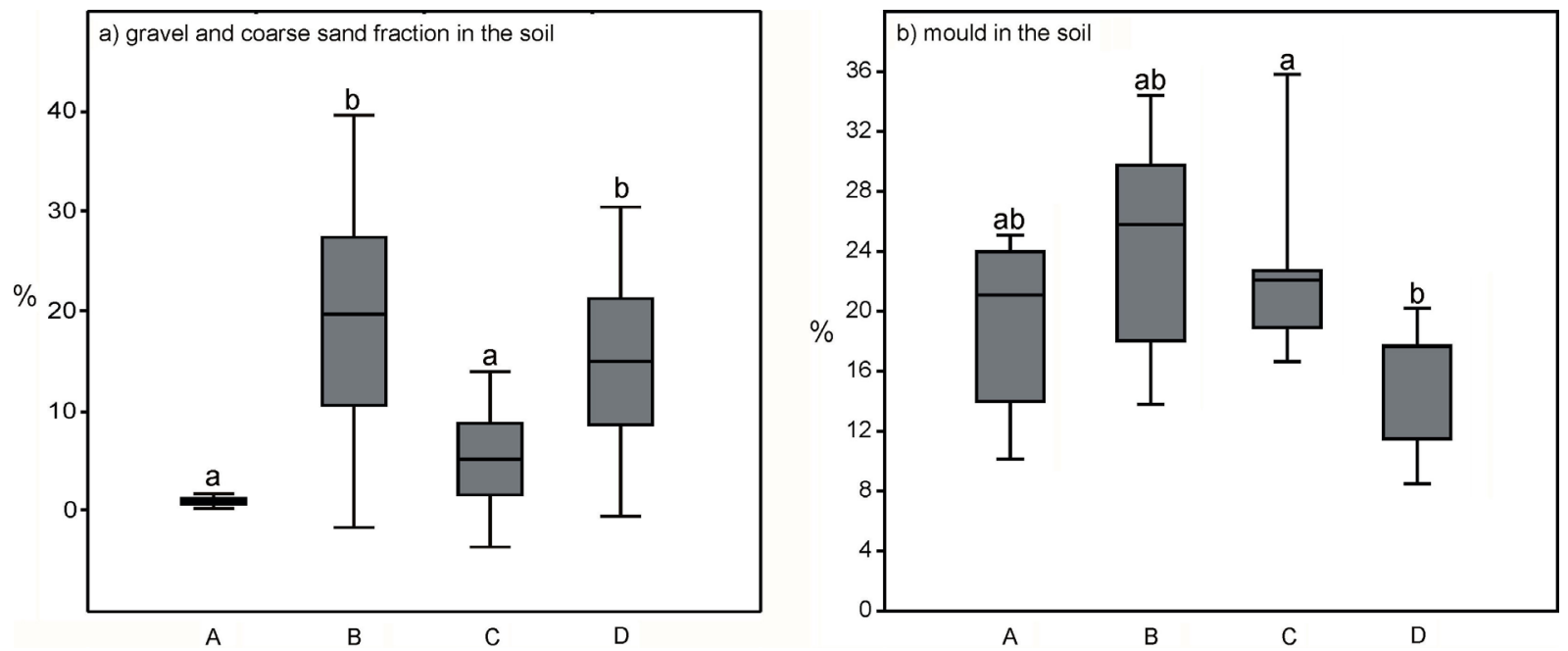

Figure 4: Mean values (min-max and \pm SE) of the most determinative soil parameters in the studied habitats. Different letters indicate significant differences between parameters at $\mathrm{P}<0.05$. A: xerothermic forest edges on the plateaus, $\mathrm{B}$ : karst shrub forests in south facing exposure, C: dry grasslands among forest patches on the plateaus, D: rocky grasslands in south facing exposure.

Slika 4: Povprečne vrednosti (min-max and \pm SE) najbolj pomembnih talnih dejavnikov v obravnavanih habitatih. Različne črke predstavljajo značilne razlike med dejavniki $(\mathrm{P}<0,05)$. A: kserotermni gozdni robovi na platojih, B: kraški grmičasti gozdovi na južnih pobočjih, C: suha travišča med gozdnimi zaplatami na platojih, D: kamnita travišča na južnih pobočjih. 
were the lowest in the shrub forests with south-facing exposure (B) (Figure 3a). The fluctuation of temperature in May was also the smallest in shrub forests with southfacing exposure (B) (Figure 3b). In July, the maximum temperatures in the grassland habitats $(\mathrm{C}, \mathrm{D})$ were significantly higher than in the areas of woody vegetation types (A, B) (Figure 3c). Similarly, the daily fluctuation of temperature in July was significantly higher in the grasslands $(\mathrm{C}, \mathrm{D})$ than in the xerothermic forests $(\mathrm{A}, \mathrm{B})$, and in the plateau grasslands $(\mathrm{C})$ was significantly higher than in the exposed plateau grasslands (D) (Figure 3d). The share of the gravel and coarse sand fraction of the soil structure in the plateau habitats (A, C) was significantly lower than in the exposed habitats (B, D) (Figure $4 a)$, the soil structure of these quadrats was dominated by fine fractions (A, C). The mould content of the soil of the shrub forests was higher than that of the grasslands; furthermore, the mould content of the soils of the plateau grasslands $(\mathrm{C})$ proved to be significantly higher than that of the exposed grasslands (D) (Figure 4b).

\section{Discussion}

It is known that $A$. $k$. fitzingerion the northern area-margin of the species can find habitats matching its microclimate and soil requirements (Pasuljević 1976). It usually means mosaics of rocky dry grasslands and shrub forests occurring on edges of mountains (Ljubisavljević et al. 2002, Stanković 2014, Zimić et al. 2018). Our study revealed the fundamental characteristics of natural micro-habitats of $A$. $k$. fitzingeri occurring on two prominent dolomite hills of Western Hungary. According to this, shrub forests with a south-facing exposure (B) can provide a cooler microclimate in the spring-early summer and late summer-early autumn periods (due to shading and air movement; both northerly and southerly winds intensifies on the slopes). Plateau grasslands (C) and shrubs (A) are characterised by looser soil structure. The latter fact is complemented by bare rock surfaces that are considered frequent on plateau grasslands $(\mathrm{C})$. These surfaces are not continuous but have cracks, which can offer excellent hiding places for the focal species (Herczeg et al. 2007a). A high soil mould content and less erosion of plateau grasslands $(\mathrm{C})$ enhances the closed grassland structure. The latter, combined with a warmer microclimate and a heterogeneous habitat structure, results in a high density of non-flight arthropod fauna, as a food base for lizards (Andersson et al. 2013).

Of the endangering factors listed by Herczeg et al. (2004) concerning populations of $A$. k. fitzingeri in Hungary, the erosion caused by human activities (through illegal motocross riding) is present in the Móroc-tető.
Trampling has also become an increasingly severe problem in past decades due to the increase of the mouflon population in both places (but especially on the Bér-hegy) (Kenyeres et al. 2020). It is important to note, that the revealed microhabitat characteristics of the studied mosaics can only meet the habitat requirements of $A$. $k$. fitzingeri together (Kovács \& Kiss 2016), in order to achieve conservation, the full-scale sustenance of habitat mosaics (grassland at plateau locations and with south-facing exposure, and shrub forest patches) is essential.

Global climate change is expected to have a negative impact on reptiles, e.g. causing changes in their phaenology and daily activity, a deterioration of the chances of successfully hatching and growing in the early phase of life (Araújo et al. 2006, Henle et al. 2008). Based on their revealed heterogeneous habitat character, the studied habitat-mosaics and ecotones (mosaics of hilly edaphic forest steppes, xerothermic grasslands, shrubs and open forests) can mitigate the expected negative effects of climate change.

\section{Acknowledgements}

The authors would like to express their sincere gratitude to Major Zoltán Molnár and to the Bakony Combat Training Centre for their help with admissions. We are very grateful to our reviewers for their remarks and to Rocco Labadessa, Editor of Hacquetia, for his work with our manuscript. Norbert Bauer and Zoltán Kenyeres were supported by the Balaton Uplands National Park Directorate in the framework of the Eastern Bakony Life07 Nat/H/000321a1 and the After-Life (Life07 Nat/H/000321) projects. Szilárd Szabó was supported by the Higher Education Institutional Excellence Programme (20428-3/2018/FEKUTSTRAT) of the Ministry of Human Capacities in Hungary, within the framework of the 4.thematic programme of the University of Debrecen.

Zoltán Kenyeres (D), https://orcid.org/0000-0002-0941-7254 Norbert Bauer (1), https://orcid.org/0000-0001-6037-0773

Judit Cservenka (1), https://orcid.org/0000-0002-5298-5839 Szilárd Szabó (10, https://orcid.org/0000-0002-2670-7384 


\section{References}

Andersson, P., Löfstedt, C. \& Hambäck, P. A. 2013: Insect densityplant density relationships: a modified view of insect responses to resource concentrations. Oecologia 173: 1333-1344.

DOI: https://doi.org/10.1007/s00442-013-2737-1

Araújo, M. B., Thuiller, W. \& Pearson, R. G. 2006: Climate warming and the decline of amphibians and reptiles in Europe. Journal of Biogeography 33: 1712-1728. DOI: https://doi.org/10.1111/j.13652699.2006.01482.x

Böhme, W., Lymberakis, P., Ajtic, R., Tok, V., Ugurtas, I. H., Sevinç, M., Crochet, P.-A., Haxhiu, I., Sterijovski, B., Krecsák, L., CrnobrnjaIsailović, J., Kaska, Y., Kumlutaş, Y., Avci, A. \& Jelić, D. 2017: Ablepharus kitaibelii (amended version of 2009 assessment). The IUCN Red List of Threatened Species 2017: e.T29691A115767606.

Dierschke, H. 1994: Pflanzensoziologie: Grundlagen und methoden. Ulmer, Stuttgart, 683 pp.

Fejérváry, G. J. 1912: Über Ablepharus pannonicus Fitz. Zoologische Jahrbücher. Abteilung für Systematik, Geographie und Biologie der Tiere 33: 547-574.

Fuhn, I. E. 1969: Revision and redefination of the genus Ablepharus Lichtenstein 1823 (Reptilia, Scincidae). Review Roumain de Biologie Zoologie 14: 23-41.

Gruber, U. 1981: Ablepharus kitaibelii (Bibron und Bory 1833) - Johannisechse. In: Böhme, W. (ed.): Handbuch der Reptilien und Amphibien Europas, Bd. 1, Akademische Verlagsges, Wiesbaden, pp. 297-302.

Hammer, Ø., Harper, D. А. T. \& Ryan, P. D. 2001: PAST: Paleontological Statistics Software Package for Education and Data Analysis. Palaeontologia Electronica 4: 1-9.

Henle, K., Dick, D., Harpke, A., Kühn, I., Schweiger, O. \& Settele, J. 2008: Climate change impacts on European Amphibians and Reptiles. Convention on the Conservation of European wildlife and natural habitats standing committee 28th meeting Strasbourg, 24-27 November 2008 T-PVS/Inf (2008) 11 rev.

Herczeg, G. \& Korsós, Z. 2003: Az interspecifikus kompetíció hatása a pannongyíkra (Ablepharus kitaibelii fitzingeri) egy antropogén hatásoknak kitett élöhelyen. [Competition effect on the skink Ablepharus kitaibelii fitzingeri among human caused disturbance.] Állattani Közlemények 88: 73-84. [In Hungarian]

Herczeg, G., Tóth, T., Kovács, T., Korsós, Z. \& Török, J. 2004: Distribution of Ablepharus kitaibelii fitzingeri Mertens, 1952 (Squamata: Scincidae) in Hungary. Russian Journal of Herpetology 11: 99-105.

Herczeg, G., Tóth, T., Kovács, T., Korsós, Z. \& Török, J. 2007a: Microhabitat use, seasonal activity and diet of the snake-eyed skink (Ablepharus kitaibelii fitzingeri) in comparison with sympatric lacertids in Hungary. Biologia 62: 482-487.

Herczeg, G., Török, J. \& Korsós, Z. 2007b: Size-dependent heating rates determine the spatial and temporal distribution of small-bodied lizards. Amphibia-Reptilia 28: 347-356.

Horváth, G. 1918: Kitaibel Pál állattani megfigyelései. Annales Musei historico-naturalis hungarici 16: 1-26.
Kenyeres, Z., Szabó, Sz. \& Bauer, N. 2020: Conservation possibilities of the rare grasshopper Stenobothrus eurasius Zubovski, 1898 are hampered by wild game in its fragmented western outposts. Journal of Insect Conservation 24: 115-124. DOI: https://doi.org/10.1007/ s10841-019-00186-2

Kovács, D. \& Kiss, I. 2016: Microhabitat use of different age groups of snake-eyed skink and Eastern green lizard. Amphibia-Reptilia 37: 191-198. DOI: https://doi.org/10.1163/15685381-00003039

Ljubisavljević, K., Dzukic, G. \& Kalezic, M. L. 2002: Morphological differentiation of the Snake-eyed Skink Ablepharus kitaibelii (Bibron \& Bory, 1833), in the north-western part of the species' range: systematic implications I. Herpetozoa 14: 107-121.

Mertens, R. 1952: Über den Glattechsen-Namen Ablepharus pannonicus. Zoologischer Anzeiger 149: 48-50.

Molnár V., A. 2007: Kitaibel Pál élete és öröksége. [Life and heritage of Pál Kitaibel.] Biatorbágy, Kitaibel Kiadó, 215 pp. [In Hungarian]

Natchev, N, Tzankov, N., Vergilov, V., Kummer, S. \& Handschuh, S. 2015: Functional morphology of a highly specialised pivot joint in the cranio-cervical complex of the minute lizard Ablepharus kitaibelii in relation to feeding ecology and behaviour. Contributions to Zoology 84: 13-23. DOI: https://doi.org/10.1163/18759866-08401002

Pasuljević, G. 1965: Ritam dnevne i sezonske aktivnosti Ablepharus kitaibelii (Bibron et Bory) u Jugoslaviji. Glasnik Prirodnjačkog Muzeja u Beogradu Serija 20: 311-314.

Pasuljević, G. 1966: Prilog poznavanju ekologije Ablepharus kitaibelii (Bibron et Bory). Zbornik Filozofskog Fakulteta u Prišstini 3: 459-463.

Pasuljević, G. 1975: Ishrana populacija Ablepharus kitaibelii (Bibron et Bory, 1833) u Jugoslaviji. Zbornik radova Prirodno-matematičkog fakulteta Univerziteta u Prištini 3: 39-60.

Pasuljević, G. 1976: Characteristics of habitat and factors determining distribution and activity of the species Ablepharus kitaibelii (Lacertilia: Scincidae). Acta biologiae et medicinae experimentalis 1-2: 57-63.

Puky, M., Schad, P. \& Szövényi, G. 2005: Magyarország herpetológiai atlasza [Herpetological atlas of Hungary.] Budapest, Varangy Akciócsoport Egyesület, pp. 127-131. [In Hungarian]

Rakonczay, Z. (ed.) 1989: Vörös Könyv. [Red Book.] Budapest, Akadémiai Kiadó, pp. 161-162. [In Hungarian]

Sillero, N., Campos, J., Bonardi, A., Corti, C., Creemers, R., Crochet, P.-A., Crnobrnja Isailovic, J., Denoël, M., Ficetola, G. F., Gonçalves, J., Kuzmin, S., Lymberakis, P., de Pous, P., Rodríguez, A., Sindaco, R., Speybroeck, J., Toxopeus, B., Vieites, D. R., Vences, M. 2014: Updated distribution and biogeography of amphibians and reptiles of Europe. Amphibia-Reptilia 35: 1-31. DOI: htpps://doi. org/10.1163/15685381-00002935

Stanković, B. 2014: A new locality for the Snake-eyed skink, Ablepharus kitaibelii, in Serbia. Novi nalaz ivanjskog rovaša, Ablepharus kitaibelii, u Srbiji. Hyla: 10-12.

Szunyoghy, J. 1954: Az Ablepharus kitaibeli kitaibeli Bibron \& Bory új lelőhelye Magyarországon. [A new occurrence of the Ablepharus kitaibeli kitaibeli Bibron and Bory in Hungary.] Állattani Közlemények 44: 61-62. [In Hungarian] 
Teschler, G. 1885: Ablepharus pannonicus Fitz. Mathematikai és Természettudományi Közlemények 20: 207-451. [In Hungarian]

Tóth, S. 2015: A Bakony-vidék és a Balaton-medence herpetofaunája (Amphibia-Reptilia). [Herpetofauna of the Bakony Region and the Balaton Basin (Amphibia-Reptilia)] A Bakony természettudományi kutatásának eredményei 34, Zirc, Magyar Természettudományi Múzeum Bakonyi Természettudományi Múzeuma, pp. 161-163. [In Hungarian]

Vergilov, V. 2017: Notes on the defensive behavior and activity of Ablepharus kitaibelii (Bibron \& Bory de Saint-Vincent, 1833) in Bulgaria. ZooNotes 116: 1-4.

Vergilov, V. \& Kornilev, Y. V. 2019: Injuries reflecting intra- and interspecific interactions in the Snake-eyed Skink Ablepharus kitaibelii (Bibron \& Bory de Saint-Vincent, 1833) (Squamata, Scincidae) from Bulgaria. Herpetozoa 32: 171-175. DOI: https://doi.org/10.3897/ herpetozoa.32.e37735

Zimić, A., Pećar, D. \& Jelić, D. 2018: The Snake-eyed skink, Ablepharus kitaibelii Bibron \& Bory, 1833 (Reptilia, Squamata: Scincidae) viable population re-discovered in Bosnia and Herzegovinawith morphological, ecological and conservation notes. North-Western Journal of Zoology 14: 146-148. 